\title{
UPAYA MENINGKATKAN HASIL BELAJAR SISWA DENGAN MENGGUNAKAN MODEL SCIENTIFIC PADA MATA PELAJARAN IPA KELAS IV SD NEGERI 047166 SUKADAME TAHUN PEMBELAJARAN 2018/2019
}

\author{
ICHA TERESIA GINTING \\ (PGSD FKIP UNIVERSITAS KATOLIK SANTO THOMAS)
}

\begin{abstract}
This study aims to improve student learning outcomes in science subjects in grade IV SD Negeri 047166 Sukadame by using a Scientific model. Subjects in this study were fourth grade students totaling 28 students and the object of this study was to improve student learning outcomes by using a Scientific model. This type of research is Classroom Action Research (CAR) which is divided into 3 stages, namely general ideas, exploration, and action plans. Data collection techniques used are tests and observations, tests are given as many as 10 questions in multiple choice form. The questions given were pretest, post cycle I and post cycle II. While observation includes observing teacher activities and observing student activities in the learning process.

The results of the study indicate an increase in student learning outcomes. In the pretest, it was found that the average value of 50 and the level of completeness in classical was $17.9 \%$. In cycle I experienced an increase after using a Scientific model with an average value of 72.14 , with a classical completeness level of $39.3 \%$. And after the action taken and given post cycle II, it was obtained as many as 25 students who completed their learning outcomes and 5 students who did not complete their learning outcomes with the average posttest value of cycle II increased to $84.2 \%$ and the classical completeness level reached $82.1 \%$. From the results obtained it can be concluded that the Scientific model can improve student learning outcomes in class IV SD Negeri 047166 Sukadame Learning Year 2018/2019. Based on the results of the study, the teacher is advised to use a Scientific model because it is proven to improve student learning outcomes.
\end{abstract}

\section{Keywords: Model Scientific in Natural Science Subjects}

\section{PENDAHULUAN}

\section{Latar Belakang Masalah}

Pendidikan adalah hal yang terpenting dalam kehidupan seseorang, karena pendidikan mempunyai peranan dalam menciptakan Sumber Daya Manusia (SDM) yang berkualitas. Menurut UU RI No. 20 Tahun 2003 tentang Sistem Pendidikan Nasional bahwa:

Pendidikan adalah usaha sadar dan terencana untuk mewujudkan Suasana belajar dan proses pembelajaran agar peserta didik secara aktif mengembangkan potensi dirinya untuk memiliki kekuatan spiritual agama, pengendalian diri, kepribadian, kecerdasan, akhlak mulia, serta keterampilan yang diperlukan dirinya, masyarakat, bangsa, dan Negara. 
Lembaga yang melaksanakan proses pembelajaran yang mengembangkan nilai-nilai pendidikan adalah sekolah. Sekolah merupakan salah satu tempat untuk menyalurkan nilai-nilai pendidikan kepada generasi-generasi penerus bangsa. Pelaksanaan proses belajar mengajar disekolah senantiasa diharapkan berlangsung dengan baik. Dengan demikian akan tercapai siswa yang baik pula sebagaimana yang diharapkan. Harapan tersebut terwujud dengan adanya tanggung jawab guru yang merupakan orang-orang yang terlibat secara langsung dalam dunia pendidikan untuk memanusiakan manusia dengan berbagai cara termasuk dalam penggunaan model maupun berusaha dalam pengguanaan media pengajaran yang diperlukan dalam proses belajar sesuai dengan mata pelajaran yang ada.

Guru memegang peranan penting dalam mengatasi kesulitan belajar mengajar siswa, salah satunya guru harus mampu dan memahami media pembelajaran yang sesuai sehingga siswa merasa senang daan mengerti tentang materi yang diberikan. Kesalahan dalam memilih media pembelajaran merupakan salah satu penyebab masalah dalam pembelajaran. Maka dengan itu, seorang guru diharapkan benar-benar professional dalam bidangnya, guru harus memikirkan dan membuat perencanaan secara seksama dalam meningkatkan kesempatan belajar bagi setiap siswanya serta memperbaiki setiap kualitas mengajarnya.

Di dalam pendidikan siswa sebagai subjek pendidikan, dituntut supaya aktif dalam mencari informasi dan mengeksplorasi sendiri atau secara kelompok. Guru hanya berperan sebagai fasilitator dan pembimbing ke arah pengoptimalkan pencapaian ilmu pengetahuan yang dipelajari. Diharapkan dalam proses pembelajaran siswa mau dan mampu mengemukakan pendapat sesuai dengan apa yang telah dipahami, berinteraksi secara positif antar siswa dengan siswa maupun antar siswa dengan guru apabila ada kesulitan yang dapat membuat siswa tidak dapat mengetahui tentang kehidupan sosial.

Salah satu pelajaran yang dipelajari disekolah khususnya pada jenjang sekolah dasar (SD) adalah mata pelajaran IPA. IPA merupakan konsep pembelajaran alam dan mempunyai hubungan yang sangat luas terkait dengan kehidupan manusia. Pembelajaran IPA sangat berperan dalam proses pendidikan dan juga perkembangan teknologi, karena IPA memiliki upaya untuk membangkitkan minat manusia serta kemampuan dalam mengembangkan ilmu pengetahuan dan teknologi serta pemahaman tentang alam semesta yang mempunyai banyak fakta yang belum terungkap dan masih bersifat rahasia sehingga hasil penemuannya dapat dikembangkan menjadi ilmu pengetahuan 
alam yang baru dan dapat diterapkan dalam kehidupan sehari-hari. Dengan demikian, IPA memiliki peran yang sangat penting. Kemajuan IPTEK yang begitu pesat sangat mempengaruhi perkembangan dalam dunia pendidikan terutama pendidikan IPA di Indonesia dan negara-negara maju.

Pendidikan IPA telah berkembang di Negara-negara maju dan telah terbukti dengan adanya penemuan-penemuan baru yang terkait dengan teknologi. Akan tetapi di Indonesia sendiri belum mampu mengembangkannya. Pendidikan IPA di Indonesia belum mencapai standar yang diinginkan, padahal untuk memajukan ilmu pengetahuan dan teknologi (IPTEK) Sains penting dan menjadi tolak ukur kemajuan bangsa. Kenyataan yang terjadi di Indonesia, mata plajaran IPA tidak begitu diminati dan kurang diperhatikan. Apalagi melihat kurangnya pendidik yang menerapkan konsep IPA. Permasalahan ini terlihat pada cara pembelajaran IPA serta kurikulum yang diberlakukan sesuai atau malah mempersulit pihak sekolah dan siswa didik, masalah yang dihadapi oleh pendidikan IPA sendiri berupa materi atau kurikulum, guru, fasilitas, peralatan siswa dan komunikasi antara siswa dan guru.

Namun dalam kenyataan di lapangan sekarang ini, khususnya dalam proses pembelajaran IPA di jenjang pendidikan dasar kelas IV SD Negeri 047166 Sukadame kecamatan Tiga Panah Kabupaten Karo, masih banyak siswa yang kurang aktif dan kurang berminat mengikuti pembelajaran. Pelaksanaan pembelajaran melalui model Scientific masih jarang digunakan. Selama ini guru hanya menggunakan metode ceramah, tanya jawab dan menetapkan siswa sebagai pembelajaran yang perhatiannya duduk, diam, dengar, catat, dan hafal. Dalam melakukan proses pembelajaran kegiatan pembelajaran menjadi jenuh, bosan, dan kurang menarik siswa dalam memahami mata pelajaran IPA. Guru juga dalam mengajarkan materi hanya berpusat kepada buku sehingga siswa mudah bosan karena hanya setiap hari melihat buku tidak adanya media pembelajaran ataupun bahan ajar yang dibuat oleh guru.

Data hasil belajat siswa diperoleh melalui observasi dan studi dokumentasi nilai UTS, semester ganjil pada mata pelajaran IPA tahun pelajaran 2017/2018.

Nilai UTS Semester Ganjil Pembelajaran IPA di Kelas IV SD Negeri 047166 Sukadame Tahun Pelajaran 2017/2018

\begin{tabular}{|l|l|l|l|l|l|}
\hline No & Tahun Ajaran & KKM & Nilai & Jumlah Siswa & Presentasi \\
\hline \multirow{2}{*}{1} & $2017 / 2018$ & 78 & $\leq 78$ & 18 Orang & $67 \%$ \\
\cline { 3 - 6 } & & 78 & $\geq 78$ & 9 orang & $33 \%$ \\
\hline
\end{tabular}




\begin{tabular}{|l|l|l|l|}
\hline & Jumlah & 27 orang & $100 \%$ \\
\hline
\end{tabular}

Berdasarkan tabel di atas pada tahun ajaran 2018/2019 diketahui bahwa dari 27 orang siswa yang ada di kelas IV SD Negeri 047166 Sukadame, 18 orang siswa $(67 \%)$ dinyatakan belum tuntas dan 9 orang siswa $(33 \%)$ dinyatakan tuntas atau memenuhi Kriteria Ketuntasan Minimal (KKM) yang ditentukan yaitu 78 dan nilai ratarata kelas hanya mencapai 71 .

Salah satu upaya yang dilakukan guru guna dapat meningkatkan mutu pendidikan melalui peningkatan aktivitas dan hasil belajar siswa, yaitu dengan menggunakan model pembelajaran yang efektif diterapkan oleh guru-guru. Model pembelajaran yang dapat meningkatkan hasil belajar siswa dengan menggunakan model scientific.

Model scientific adalah proses pembelajaran yang dirancang sedemikian rupa agar peserta didik secara aktif mengkonstruksi konsep, hukum atau prinsip melalui tahapan-tahapan mengamati (untuk mengidentifikasi atau menemukan masalah), merumuskan masalah, mengajukan atau merumuskan hipotesis, mengumpulkan data dengan berbagai teknik, menganalisis data, menarik kesimpulan dan mengkomunikasikan konsep, hukum atau prinsip yang ditemukan.

Penerapan pendekatan scientific dalam pembelajaran melibatkan keterampilan proses seperti mengamati, mengklasifikasi, mengukur, meramalkan, menjelaskan, dan menyimpulkan. Dalam melaksanakan proses-proses tersebut, bantuan guru diperlukan. Akan tetapi bantuan guru tersebut semakin berkurang dengan semakin bertambah dewasanya siswa atau tingginya kelas siswa.

Penelitian yang menggunakan model Scientific pada mata pelajaran IPA yang telah dilakukan oleh Nurma Istighfaroh (2017) yang berjudul Peningkatan Hasil Belajar IPA Materi Daur Hidup Hewan Melalui Pendekatan scientific pada Siswa Kelas IV MI Ma'arif Gedangan Kecamatan Tuntang Kabupaten Semarang Tahun Ajaran 2016/2017. Hasil belajar siswa mengalami peningkatan.

Alasan peneliti memilih model scientific karena adanya beberapa hal yang dianggap lebih unggul dalam rangka meningkatkan hasil belajar IPA yaitu proses pembelajaran lebih menarik, sebab siswa tidak hanya mendengarkan guru menjelaskan. Berdasarkan uraian diatas peneliti terdorong untuk melakukan penelitian lanjutan untuk mengetahui bagaimana sebenarnya hasil belajar siswa dengan menggunakan model 
scientific, sehingga peneliti mengambil judu "Upaya Meningkatkan Hasil Belajar Siswa Dengan Menggunakan Model Scientific Pada Mata Pelajaran IPA Kelas IV Sd Negeri 047166 Sukadame Tahun Pembelajaran 2018/2019”.

\section{Identifikasi Masalah}

Berdasarkan latar belakang masalah di atas, maka permasalahan pada penelitian ini dapat diidentifikasi sebagai berikut:

1. Guru pada umumnya mengajar dengan ceramah

2. Guru dan siswa hanya berpusat pada buku paket di sekolah

3. Proses pembelajaran kurang aktif

4. Hasil belajar siswa masih rendah.

\section{Batasan Masalah}

Berdasarkan latar belakang dan identifikasi masalah di atas, maka yang menjadi batasan masalah dalam penelitian ini adalah "Upaya Meningkatkan Hasil Belajar Siswa Menggunakan Model Scientific Pada Mata Pelajaran IPA Materi Bagian-bagian Tumbuhan di Kelas IV SD Negeri 047166 Sukadame Tahun Pembelajaran 2018/2019.

\section{Rumusan Masalah}

Berdasarkan pembatasan masalah di atas, yang menjadi rumusan masalah pada penelitian ini adalah:

1. Bagaimanakah proses pelaksanaan pembelajaran dengan menggunakan model scientific pada mata pelajaran IPA kelas IV SD Negeri 047166 Sukadame kecamatan Tiga Panah Kabupaten Karo Tahun Pembelajaran 2018/2019?

2. Apakah dengan menggunakan model scientific dapat meningkatkan hasil belajar siswa pada mata pelajaran IPA kelas IV SD Negeri 047166 Sukadame kecamatan Tiga Panah Kabupaten Karo Tahun Pembelajaran 2018/2019?

\section{Tujuan Penelitian}

Sesuai dengan rumusan masalah di atas, maka tujuan yang dicapai dalam penelitian adalah:

1. Untuk mengetahui proses pelaksanaan pembelajaran siswa yang diajarkan dengan menggunakan model scientific pada mata pelajaran IPA kelas IV SD Negeri 047166 Sukadame Kecamatan Tiga Panah Kabupaten Karo Tahun Pembelajaran 2018/2019. 
2. Untuk meningkatkan hasil belajar siswa dengan menggunakan model scientific pada mata pelajaran IPA kelas IV SD Negeri 047166 Sukadame Kecamatan Tiga Panah Kabupaten Karo Tahun Pembelajaran 2018/2019.

\section{Manfaat Penelitian}

Adapun beberapa yang ingin di peroleh dari penelitian ini adalah sebagai berikut:

1. Bagi guru, sebagai bahan pertimbangan dalam pemilihan model pembelajaran, yaitu model scientific. Melalui penggunaan model ini dalam pembelajaran IPA, siswa menemukan dan menyelidiki sendiri materi yang dipelajari sehingga mengembangkan cara berpikir aktif dan kreatif.

2. Bagi siswa, dapat meningkatkan hasil belajar siswa dalam pembelajaran IPA dan menjadikan siswa-siswi yang aktif serta kreatif dalam belajar melalui pembelajaran IPA dengan menggunakan model scientific.

3. Bagi sekolah, untuk membantu sekolah dalam mengembangkan dan menciptakan lembaga yang berkualitas.

4. Bagi mahasiswa peneliti, sebagai masukan dalam memperdalam ilmu tentang cara menggunakan model scientific dalam pembelajaran IPA. Bila sesuai dengan hasil yang diharapkan dalam penerapannya dapat digunakan sebagai model yang akan dipakai nanti bila menjadi guru dalam pembelajaran IPA.

\section{METODOLOGI PENELITIAN}

\section{Pendekatan dan Metode Penelitian}

Pendekatan yang digunakan dalam penelitian ini adalah pendekatan campuran. Pendekatan yang dimaksud campuran adalah merupakan gabungan dari dua metode yaitu mode kualitatif dan metode kuantitatif. Penggunaan dua metode ini dipandang lebih memberikan pemahaman yang lebih lengkap tentang permasalahan penelitian dari pada salah satu penggunaan metode tersebut. Metode yang digunakan adalah penelitian tindakan kelas. Penelitian tindakan kelas adalah penelitian praktis yang dilakukan oleh guru untuk memperbaiki proses belajar mengajar baik dari alat, media, sumber, metode, strategi, maupun model yang digunakan guru. 
Jenis penelitian ini bertujuan memperbaiki proses pembelajaran dalam meningkatkan hasil belajar siswa dalam pelajaran Ilmu Pengetahuan Alam (IPA) pada materi bagian-bagian tumbuhan menggunakan model scientific di kelas IV SD Negeri Sukadame tahun pembelajaran 2018/ 2019

\section{Tempat dan Waktu Penelitian}

\section{Tempat Penelitian}

Penelitian ini dilakukan di sekolah SD Negeri 047166 Sukadame Kecamatan Tiga Panah Kabupaten Karo. Alasan peneliti memilih lokasi penelitian ini didasarkan atas pertimbangan sebagai berikut :

1) SD Negeri 047166 Sukadame belum pernah diadakan penelitian dengan judul yang sama dengan judul peneliti Upaya Meningkatkan Hasil Belajar Siswa Dengan Menggunakan Model Scientific Pada Mata Pelajaran IPA Kelas IV.

2) Pelaksanaan pembelajaran di SD Negeri 047166 Sukadame tersebut masih belum optimal dan hasil belajar siswa belum optimal

\section{Waktu Penelitian}

Penelitian ini dilakukan pada semester ganjil tahun pembelajaran 2018/2019. Waktu pelaksanaan penelitian dilakukan pada bulan maret sampai bulan oktober 2018 .

\section{Subjek Penelitian}

Subjek penelitian ini adalah siswa kelas IV SD Negeri 047166 Sukadame tahun pembelajaran 2018/ 2019 yang berjumlah siswa 28 orang siswa. Dari 28 orang siswa terdapat 10 orang siswa laki-laki dan 18 orang siswa perempuan. Usia di kelas ini berkisar 9-11 tahun dengan tingkat kecerdasan yang berbeda. Siswa bertempat tinggal di sekitar sekolah yang berlokasi di desa Sukadame Kecamatan Tiga Panah Kabupaten Karo. Kelas ini menjadi subjek penelitian karena mengalami masalah bevlajar dalam pembelajaran.

Objek dari penelitian ini adalah : (a) hasil belajar siswa, (b) model pembelajaran Scientific.

\section{Jenis dan Sumber Data}

\section{Jenis Data}


Data yang diperoleh pada penelitian ini adalah data kuantitatif dan data kualitatif.

a. Kualitatif yaitu suatu penelitian yang bersifat menggambarkan kenyataan atau fakta sesuai dengan data yang diperoleh, dengan tujuan untuk mendeskripsikan aktivitas guru dan siswa selama proses pembelajaran.

b. Kuantitatif yaitu suatu penelitian yang memberikan nilai berupa angka pada tes.

\section{Sumber Data}

Sumber data yang diperlukan berasal dari tiga sumber yaitu:

a. Informan dan narasumber: yaitu guru kelas IV dan siswa kelas IV SD Negeri 047166 Sukadame

b. Tempat dan peristiwa berlangsung aktivitas pembelajaran IPA yaitu SD Negeri 047166 Sukadame

c. Daftar nilai mata pelajaran IPA siswa kelas IV SD Negeri 047166 Sukadame.

\section{Teknik dan Alat Pengumpulan Data Observasi}

\section{Observasi}

Observasi merupakan teknik mengumpulkan data dengan cara mengamati setiap kejadian yang sedang berlangsung. Observasi juga berhubungan dengan kegiatan guru dan siswa.

\section{Lembar Observasi Kegiatan Guru}

Lembar observasi pada aktivitas guru digunakan untuk melihat pelaksanaan pembelajaran yang diadakan guru di dalam kelas selama proses pembelajaran berlangsung dengan menggunakan model scientific. Dalam melakukan observasi di kegiatan guru dibantu oleh observer dengan tujuan untuk memperoleh data. Penetapan skor untuk instrumen penelitian berupa angket, menggunakan skala likert. Adapun aspek yang diamati dalam kegiatan mengajar selama proses pembelajaran

\section{Lembar Observasi Aktivitas Siswa}

Observasi kegiatan siswa digunakan untuk melihat bagaimana aktivitas maupun kegiatan yang dilakukan siswa selama mengikuti proses pembelajaran. Dalam melakukan observasi di kegiatan siswa dibantu juga oleh observer dengan tujuan untuk memperoleh data.

Penetapan skor untuk instrumen penelitian berupa angket, menggunakan skala likert. Adapun aspek yang diamati dalam kegiatan siswa selama pembelajaran

\section{Tes}


Tes merupakan alat pengukur data yang berharga dalam penelitian. Tes ialah seperangkat pasangan (stimulus) yang diberikan kepada seseorang dengan maksud untuk mendapatkan jawaban-jawaban yang dijadikan penetapan skor angka. Adapun jenid tes dalam penelitian adalah tes prestasi belajar dan tes kecerdasan.

\section{Dokumentasi}

Dokumentasi dilaksanakan dengan menyertakan dokumen yang berkaitan seperti silabus, RPP, LKS, dsb beserta gambar atau foto pada saat dilaksanakan penelitian.

\section{Uji Validitas Data dan Reliabilitas}

\section{Uji Validitas}

Sebelum instrumen diuji cobakan, terlebih dahulu yang dilakukan peneliti adalah validitas terhadap tes tertulis dan RPP (perangkat pembelajaran) yang telah dirancang, serta lembar instrumen pendukung penelitian (lembar observasi guru) terhadap penggunaan model pembelajaran scientific.

Untuk mengetahui validitas dari soal tersebut maka digunakan rumusan sebagai berikut:

$r_{x y}=\frac{N \Sigma x y-(\Sigma x)(\Sigma y)}{\sqrt{\left(\Sigma x^{2}-\left(\Sigma x^{2}\right)\right\}\left(N \Sigma y^{2}-(\Sigma y)^{2}\right)}} \ldots \ldots \ldots \ldots \ldots \ldots \ldots$ (Arikunto, 2017: 87)

Keterangan :

$r_{x y}=$ Koefisien korelasi antara variabel $\mathrm{X}$ dan $\mathrm{Y}$

$\mathrm{N} \quad=$ Banyaknya subjek pengikut

$\sum x y=$ Jumlah perkalian $\mathrm{x}$ dan $\mathrm{y}$

$\mathrm{X}=$ Nilai pembanding

$\mathrm{Y}=$ Nilai dari instrument yang akan dicari validitasnya

\section{Uji Reliabilitas}

Untuk menguji reliabilitas tes, maka digunakan KR-20 dengan rumusan sebagai berikut:

$r_{11}=\left[\frac{n}{n-1}\right]\left[1-\Sigma \frac{s_{1}^{2}}{s_{1}^{2}}\right]$ ( Purwanto, 2017: 175)

Keterangan: 
$r_{11}=$ Reliabilitas yang dicari

$n$ = Banyaknya butir soal

$\sum S_{1}^{2}=$ Jumlah varians skor tiap-tiap item

$s_{1}^{2} \quad=$ Varians skor total

Interpretasi terhadap nilai koefisien $\mathrm{r}_{11}$ digunakan kreteria sebagai berikut:

$\mathrm{R}_{11} \leq 0,20 \quad$ : reliabilitas sangat rendah

$0,20<\mathrm{r}_{11} 0,40 \quad$ : reliabilitas rendah

$0,40<\mathrm{r}_{11} 0,70 \quad:$ reliabilitas sedang

$0,70<\mathrm{r}_{11} 0,90 \quad$ : reliabilitas tinggi

$0,90<\mathrm{r}_{11} 1,00 \quad$ :reliabilitas sangat tinggi

\section{Analisis Data}

Penelitian ini mengkaji data dalam dua jenis yaitu data kuantitatif yang diperoleh dari test siswa dan data kualitatif yang diperoleh dari keterangan dan komentar lembar observasi guru dan teman sejawat.

\section{Hasil Pelaksanaan Pembelajaran}

Untuk menganalisis data hasil pelaksanaan pembelajaran dengan menggunakan model scientific, maka analisisnya sebagai berikut:

a. Aktivitas guru

Untuk mengetahui pelaksanaan pembelajaran aktivitas guru digunakan rumus:

Nilai $=\frac{\text { Total Skor (perolehan) }}{\text { Skor Maksimal }} \times 100 \%$

Kriteria Penilaian dalam Pelaksanaan Pembelajaran Guru

\begin{tabular}{|l|l|}
\hline Kriteria Penilaian & Keterangan \\
\hline $\mathrm{A}=81-100$ & Baik sekali \\
\hline $\mathrm{B}=61-80$ & Baik \\
\hline $\mathrm{C}=41-61$ & Cukup \\
\hline $\mathrm{D}=21-40$ & Kurang \\
\hline $\mathrm{E}=0-20$ & Sangat Kurang \\
\hline
\end{tabular}

Sumber: Saur Tampubolon2014:35

b. Aktivitas siswa

Untuk mengetahui pelaksanaan pembelajaran aktivitas siswa, dengan menggunakan rumus: 


$$
\text { Nilai }=\frac{\text { Total Skor (perolehan) }}{\text { Skor Maksimal }} \text { X } 100
$$

Kriteria Penilaian dalam Pelaksanaan Pembelajaran Siswa

\begin{tabular}{|l|l|}
\hline Kriteria Penilaian & Keterangan \\
\hline $80-100$ & Baik sekali \\
\hline $70-79$ & Baik \\
\hline $60-69$ & Cukup \\
\hline $50-59$ & Kurang \\
\hline $0-49$ & Gagal \\
\hline
\end{tabular}

Sumber: Syah 2017: 151

\section{Ketuntasan Hasil Belajar Siswa}

\section{Ketuntasan Individual}

Ketuntasan individual dapat dikatakan tuntas belajar jika proporsi jawaban benar siswa mencapai nilai KKM yang ditetapkan sekolah yaitu memperoleh nilai 78. Rumus untuk menghitung ketuntasan individu adalah sebagai berikut:

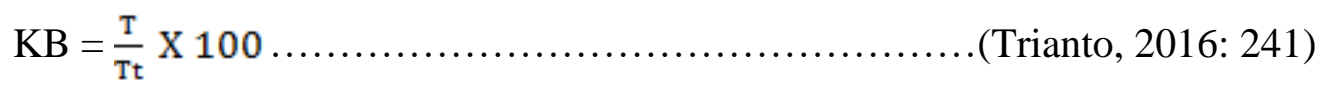

Keterangan:

$K B=$ Ketuntasan belajar

$\mathrm{T}=$ Jumlah skor yang diperoleh siswa

$T_{t}=$ Jumlah skor total

\section{Ketuntasan Klasikal}

Ketuntasan klasikal dapat dikatakan tuntas belajar jika di dalam kelas tersebut terdapat $78 \%$ siswa yang sudah tuntas belajarnya. Rumusan untuk menghitung ketuntasan klasikal adalah sebagai berikut :

$\mathrm{P}=\frac{\text { 2siswayangtuntas }}{\sum \text { siswa }} \times 100 \%$

( Aqib,dkk. 2016: 205)

\section{Penilaian Rata-Rata}

Analisis data digunakan untuk mengetahui berhasilnya atau tindakan yang dilakukan dalam penelitian.Sesuai dengan tujuan penelitian, maka analisis data yang dilakukan adalah penilaian rata-rata.

Untuk mencari rumus rata-rata nilai dalam kelas adalah sebagai berikut: 
$\mathrm{X}=\frac{2 X}{N}$ ..( Sudjana, 2016: 109)

Keterangan:

$\mathrm{x}=$ Nilai rata-rata

$\Sigma \mathrm{X}=$ Jumlah seluruh skor

$\mathrm{N}$ = Banyaknya objek

\section{Indikator Kinerja Penelitian}

Penelitian kelas dikatakan berhasil apabila dilakukan tindakan perbaikan kualitas pembelajaran. Indikator yang ingin dicapai dalam penelitian ini adalah meningkatkan hasil belajar IPA kelas IV SD Negeri 047166 Sukadame

1. Indikator keberhasilan hasil belajar siswa minimal $80 \%$ dari jumlah siswa mencapai KKM dengan cara mengukur dari hasil tes dalam mengerjakan soal peristiwa alam di Indonesia dan menghitung berapa siswa yang menjawab benar.

2. Indikator keberhasilan kualitas keaktifan guru pada saat proses pembelajaran berlangsung minimal $85 \%$ dengan cara mengukur dari hasil observasi kinerja guru dalam penerapan model Scientific.

3. Indikator keberhasilan kualitas keaktifan siswa pada saat proses pembelajaran berlangsung minimal $85 \%$ dengan cara mengukur dari hasil observasi keaktifan siswa dalam proses pembelajaran berlangsung.

\section{Desain Penelitian}

Desain penelitian yang digunakan dalam penelitian ini adalah Penelitian Tindakan Kelas (PTK) dengan model desain penelitian yang dikemukakan oleh Elliot dalam melaksanakan PTK terdapat 4 tahapan yaitu gagasan umum, eksplorasi, rencana dan tindakan. Berikut ini daur siklus dalam penelitian tindakan kelas:

\section{Prosedur Penelitian}

Penelitian ini direncanakan dilaksanakan dalam dua siklus dan masing-masing siklus terdiri dari dua kali pertemuan.Untuk memperlancar jalannya penelitian, peneliti menyusun langkah-langkah penelitian yang terdiri dari gagasan umum, eksplorasi, rencana dan tindakan.

\section{HASIL DAN PEMBAHASAN PENELITIAN}


Dari hasil pengamatan hasil belajar ataupun ketuntasan belajar dimulai dari pre test, post test siklus I dan post test siklus II, terlihat adanya peningkatan yang baik dicapai siswa. Hal tersebut membuktikan hipotesis poenelitian yaitu model scientific dalam proses pembelajaran telah dilaksanakan secara optimal dan sesyuai dengan tujuan yang diharapkan. Berdasarkan analisis data pre test, siklus I dan siklus II dapat dilijat pada tabel berikut ini.

Tabel 4.11 Peningkatan Nilai Pretest, Siklus I dan Siklus II

\begin{tabular}{|c|c|c|c|c|}
\hline No & Nama Siswa & pretest & Siklus I & Siklus II \\
\hline 1 & Aprilia Br Siregar & 20 & 90 & 90 \\
\hline 2 & Imelda Wati Br Sitepu & 40 & 70 & 90 \\
\hline 3 & Apryana Natasya Br Perangin-Angin & 70 & 70 & 100 \\
\hline 4 & Alpin Rahmat Dani P & 20 & 60 & 70 \\
\hline 5 & Aurel Christyani Br Ginting & 30 & 80 & 90 \\
\hline 6 & Aril Ginting & 90 & 100 & 100 \\
\hline 7 & Bunga Br Tarigan & 80 & 90 & 80 \\
\hline 8 & Bima Akbar Sanjaya & 50 & 70 & 80 \\
\hline 9 & David Ilego Nainggolan & 40 & 70 & 80 \\
\hline 10 & Glen Aliska Sembiring & 60 & 50 & 70 \\
\hline 11 & Ibredi & 70 & 80 & 90 \\
\hline 12 & Jelsi Olimfia Br Tarigan & 20 & 60 & 80 \\
\hline 13 & Kalvin Ginting & 20 & 90 & 90 \\
\hline 14 & Marsya Natha Nela Br T & 80 & 100 & 100 \\
\hline 15 & Meikel Siregar & 60 & 60 & 90 \\
\hline 16 & Muhamad Rivail & 40 & 80 & 90 \\
\hline 17 & Maini Abel Br Aritonang & 40 & 70 & 60 \\
\hline 18 & Novri Tania Margaretta Sitepu & 30 & 30 & 70 \\
\hline 19 & Anisa & 30 & 50 & 70 \\
\hline 20 & Restina Br Marbun & 90 & 90 & 80 \\
\hline 21 & Siren Nathasa Br Sitepu & 40 & 100 & 90 \\
\hline 22 & Silvia Olivia Br Tarigan & 40 & 70 & 80 \\
\hline 23 & Tri Wulandari & 50 & 70 & 80 \\
\hline 24 & Vanesia Cella Br Situmorang & 70 & 70 & 80 \\
\hline 25 & Yuda Tanda Trisna Ginting & 50 & 50 & 100 \\
\hline
\end{tabular}




\begin{tabular}{|l|l|l|l|l|}
\hline 26 & May Christiany Br Sembiring & 40 & 60 & 90 \\
\hline 27 & Tiara Rastiani & 80 & 60 & 80 \\
\hline 28 & Charen Dwi Fortuna Siregar & 50 & 80 & 90 \\
\hline$\sum \mathbf{N}$ & $\mathbf{1 4 0 0}$ & $\mathbf{2 0 2 0}$ & $\mathbf{2 3 6 0}$ \\
\hline $\mathbf{X}$ & $\mathbf{5 0}$ & $\mathbf{7 2 , 1 4}$ & $\mathbf{8 4 , 2}$ \\
\hline N & $\mathbf{2 8}$ & $\mathbf{2 8}$ & $\mathbf{2 8}$ \\
\hline
\end{tabular}

Dari tabel diatas dapat dilihat peningkatan hasil pretest nilai ratanya adalah 50\%, pada siklus I nilai rata-ratanya adalah $72,14 \%$ dan pada siklus II terdapat nilai rataratanya $84,2 \%$. Jadi dapat disimpulkan bahwa pembelajaran dengan menggunakan model scientific pada mata pelajaran IPA dengan materi bagian-bagian tumbuhan dapat meningkatkan hasil belajar siswa. Untuk lebih jelasnya dapat dilihat pada gambar diagram di bawah ini.

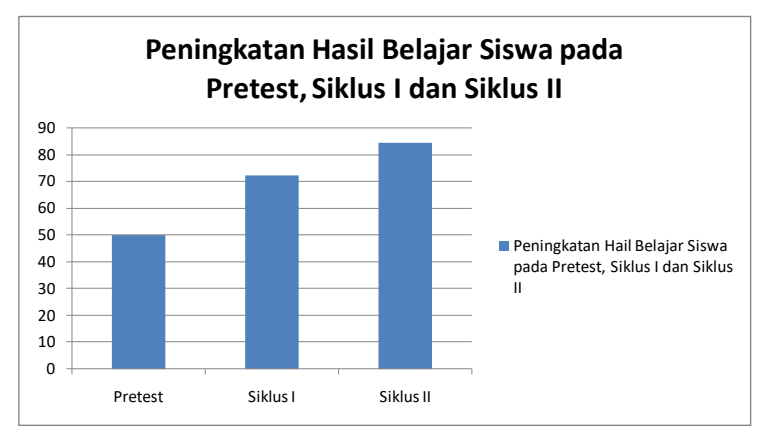

\section{Gambar 4.5 Peningkatan Hasil Belajar Siswa pada Pretest, Siklus I dan Siklus II}

\subsection{Penguji Hipotesis Tindakan}

Dari pembahasan yang telah diperoleh peneliti bahwa terdapat peningkatan hasil belajar yang baik dari siklusI dan siklus II. Peneliti ini dikatakan berhasil apabila ketuntasan hasil belajar siswa secara klasikal mencapai $78 \%$ dan pada siklus II diperoleh ketuntasan hasil belajar secara klasikal 84,2\%. Jadi dapat disimpulkan bahwa melalui temuan yang diperoleh peneliti dapat mermberikan jawaban terhadap hipotesis 
tindakan yang telah dikemukakan sebelumnya bahwa dengan penerapan model scientific terjadi peningkatan terhadap hasil belajar IPA siswa kelas IV SD Negeri 047166 Sukadame.

\section{PENUTUP}

\section{Simpulan}

Berdasarkan hasil penelitian pada pelaksanaan tindakan terhadap proses pembelajaran dengan menggnakan model scientific maka dapat disimpulkan yaitu:

1. Aktivitas guru dalam pembelajaran IPA pada materi Bagian-bagian Tumbuhan dengan menggunakan model scientific terjadi peningkatan. Hal ini dapat dilihat berdasarkan rata-rata persentase skor aktivitas guru pada siklus I 75\% masih kategori baik pada siklus II sebesar 97,5\% dan sudah dalam kategori baik sekali dan telah memenuhi indikator keberhasilan.

2. Aktivitas siswa dalam pembelajaran IPA pada materi bagian-bagian tumbuhan dengan menggunakan model scientific terjadi peningkatan. Hal ini dapat dilihat berdasarkan rata-rata persentase skor aktivitas siswa pada siklus I 73,33\% dalam kategori baik pada siklus II sebesar 93,33\% dan sudah dalam kategori baik sekali dan telah memenuhi indikator keberhasilan.

3. Hasil belajar siswa dalam pembelajaran IPA pada materi bagian-bagian tumbuhan dengan mnggunakan model scientific terjadi peningkatan. Hal ini dapat dilihat dari persentase ketuntasan belajar klasikal pada pretest 50, pada siklus I 72,14, dan pada siklus II 84,2 .

\section{Saran}

Berdasarkan penelitian yang dilakukan, maka saran yang dapat diberikan adalah sebagai berikut.

1. Bagi guru, agar mempertimbangkan menggunakan model scientific dalam meningkatkan kegiatan proses pembelajaran. Dimana model scientific dapat meningkatkan hasil belajar yang dilakukan oleh guru dalam membelajarkan IPA.

2. Bagi peneliti selanjutnya, diharapkan dapat melakukan atau melanjutkan penelitian yang sama mengenai upaya meningkatkan hasil belajar siswa dengan menggunakan model scientific dalam pembelajaran sehingga diperoleh hasil belajar jauh lebih baik daripada peneliti sebelumnya. 


\section{DAFTAR PUSTAKA}

Aqib, Zainal, dkk. 2016. Penelitian Tindakan Kelas. Bandung: Yrama Widya

Daryanto, 2014. Pendekatan Moral Scientific Kurikulum 2013. Yogyakarta: Gava Media

Dimyanti dan Mudjino, 2013. Belajar dan Pembelajaran. Jakarta: Rineka Cipta

Hamalik, Oemar. 2013. Kurikulum dan Pembelajaran. Jakarta: Bumi Aksara

Istarani dan Intan Pulungan, 2017.Ensiklopedia Pendidikan. Media Lanspa

Jihad, Asep.Haris, Abdul. 2013. Evaluasi Pembelajaran. Yogyakarta: Multi Pressindo

Purwanto. 2010. Evaluasi Hasil Belajar. Yogyakarta: Pustaka Belajar

Slameto. 2010. Belajar dan Faktor- Faktor yang Mempengaruhinya. Jakarta: Rineka Cipta

Sudjana, Nana. 2016. Penilaian Hasil Proses Belajar. Bandung: PT Remaja Poelakarya

Susanto. 2013. Teori Belajar dan Pembelajaran di Sekolah Dasar. Jakarta: Prenadamedia Group

Tampubolon, Saur. 2014. Penelitian Tindakan Kelas sebagai Pengembangan Profesi Pendidik dan Keilmuan, jakarta: Erlangga

Trianto. 2009. Mendesain Model Pembelajaran Inovatif Progresif. Jakarta: Prenadamedia Group

trianto. 2013. Model Pembelajaran Terpadu. Jakarta: Bumi Aksara

wisudawati. Sulistyowati, Eka. 2014. Metodologi Pembelajaran IPA. Jakarta: PT Bumi Aksara 